\title{
The Importance of Increasing Minimum Age For Marriage In Indonesian Marriage Law*
}

\author{
Holijah $^{1}$ \& Jariyah binti Abd Manaf ${ }^{2}$
}

\begin{abstract}
The Importance of Increasing Minimum Age For Marriage In Indonesian Marriage Law. This article discusses the changes in the minimum age for marriage as regulated in Law Number 1 of 1974 concerning marriage, which was later amended by Law No. 16 of 2019 on the same topic. In Law no. 1/1974, the minimum age for marriage for the prospective groom and bride is differentiated in which for the prospective groom the minimum age for marriage is 19 years while for the bride is 16 years. This kind of distinction was later removed by Law No. 16 of 2019 which stipulates the minimum age for marriage for the prospective groom and bride to be the same, namely 19 years. This change in minimum limits is really important as it can have positive effects, especially for women, as they can be physically and psychologically ready to become a wife as well as a mother for their children. Indeed, physical and mental maturity for someone intending to get married is important. This is also following the principles of Islamic Law which view that marriage requires physical and spiritual readiness and that the family is the main source for producing quality human beings.
\end{abstract}

Keywords: minimum age for marriage, marriage law in Indonesia

\begin{abstract}
Abstrak: Pentingnya Peningkatan Batas Minimum Usia Menikab dalam UndangUndang Perkawinan Indonesia. Artikel ini membahas tentang perubahan batas minimal usia menikah sebagaimana diatur dalam Undang-Undang Nomor 1 Tahun 1974 tentang perkawinan, yang kemudian diubah oleh Undang-Undang No 16 Tahun 2019 pada topik yang sama. Di dalam UU No. 1/1974 batas minimal usia menikah bagi calon mempelai laki-laki dan calon mempelai wanita dibedakan hal mana untuk calon mempelai laki-laki batas minimal usia menikah adalah 19 tahun dan calon mempelai wanita adalah 16 tahun. Pembedaan semacam ini kemudian dihapus oleh UU No 16 Tahun 2019 yang menetapkan batas minimal usia menikah bagi calon mempelai laki-laki dan calon mempelai perempuan adalah sama yakni 19 tahun. Perubahan batas minimal ini dapat memberikan efek positif khususnya bagi kaum wanita agar mereka dapat siap baik secara fisik maupun psikis untuk menjadi seorang istri sekaligus sebagai ibu dari anak-anaknya. Memang, kedewasaan fisik maupun mental bagi seseorang yang bermaksud melangsungkan perkawinan merupakan aspek penting; Hal ini sesuai pula dengan prinsip Hukum Islam yang memandang bahwa pernikahan membutuhkan kesiapan lahir dan bathin dan bahwa keluarga adalah sumber utama untuk melahirkan manusia yang berkualitas.
\end{abstract}

Kata Kunci: batas minimal usia menikah, hukum perkawinan di Indonesia

\footnotetext{
* This article is developed from the paper presented in international seminar on Islamic family law in Bengkulu.

${ }^{1}$ Lecturer at Faculty of Sharia and Law, UIN Raden Fatah Palembang

${ }^{2}$ Student of Master Program in Fiqh and Ushlul Fiqh at Malaysia International Islamic University

E-mail: 'holijah_uin@radenfatah.ac.id, ${ }^{2}$ cahayaiman119@gmail.com
} 


\section{Introduction}

Before discussing further the importance of increasing the minimum age of marriage in Indonesia's Marriage Law, the author will first explain the term "marriage". In Indonesia, the term "marriage" can be translated into "pernikahan" as well as "perkawinan". The two terms are often interchangeably used; the term "pernikahan" which is formed from the root word "nikah" is often equated with the term "perkawinan" which comes from the word "kawin". In terms of etymology, the equation is not quite right, because the words "kawin" and "nikah" each has a different meaning. ${ }^{1}$ The word "kawin" is used generally for all living things, while the word "marriage" is specifically for humans. Apart from that, the word "kawin" also implies "intercourse." while the word "marriage" means the relationship between men and women. ${ }^{2}$ What is meant by early age marriage or immature marriage is, "a marriage that is carried out through civil, religious or customary law, and with or without official registration or approval where one or both partners are children under 18 years of age". ${ }^{3}$ In this article, the term marriage is not interpreted as a sexual relationship but a physical and spiritual bond between a man and a woman as husband and wife to form a happy and eternal family (household) based on Islamic teachings.

Furthermore, as it is commonly understood, the regulation regarding marriage in Indonesia is regulated in Law Number 1 of 1974 concerning Marriage. The statute stipulates that the implementation of a marriage can only be carried out if the age of the prospective bride and groom has reached a minimum age of 19 years for men and 16 years for women. ${ }^{4}$ In the case that the provisions in paragraph 1 cannot be fulfilled, then

${ }^{1}$ The word "nikah" means forming a family with the opposite sex, where the term "kawin/ mating" is used generally for plants, animals, and humans and denotes a naturally progressive process. "Nikah" is only used for human contexts because it contains validity under national law, customs, and especially according to religious values. See H.M.A Tihami and Sohari Sahrani, Fikih Munakahat: Complete Marriage Fiqh Study, (Jakarta: Raja Grafindo Persada, 2014), p. 7.

${ }^{2}$ Abd. Rachman Assegaf, Studi Islam Kontekstual Elaborasi Paradigma Baru Muslim Kaffah, (Yogyakarta: Gema Media, 2005), p. 131.

${ }^{3}$ Badan Pusat Statistik (BPS) dan UNICEF, Kemajuan Tertunda: Analisis Data Perkawinan Usia Anak di Indonesia, (Jakarta: Badan Pusat Statistik, 2015), p. 7.

${ }^{4}$ Article 7 paragraph (1) of Law No. 1 of 1974 concerning Marriage. 
the marriage can take place after the parents of the male or female party obtain a court dispensation. ${ }^{5}$

The above provisions are subsequently amended by Law Number 16 of 2019 concerning Amendments to Law Number 1 of 1974 concerning Marriage which states that marriage is only permitted if the man and woman have reached the age of 19 (nineteen) years. ${ }^{6}$ In the case that (2) There is a deviation from the age requirement as referred to in paragraph (1), the parent of the male and/or the parent of the female party may request dispensation to the Court on very urgent grounds accompanied by sufficient supporting evidence. ${ }^{7}$ The increase in the minimum age for marriage for women from 16 years to 19 years has a very important positive impact not only normatively but also health, economically, and socially.

This paper presents several concrete examples of the positive impact of increasing the minimum age for marriage and its relevance to efforts to improve the quality of human resources, especially for women.

\section{Development of Early Marriage Cases In Indonesia}

According to a 2017 Central Statistics Agency report, the rate of child marriage in Indonesia in 23 provinces shows 25 percent. ${ }^{8}$ The prevalence of early childhood marriage above shows that in the last three decades there has been a decrease in the number of cases more than doubled which at the same time indicates that the Indonesian people have become increasingly aware that early marriage should not be carried out. This phenomenon, however, still makes Indonesia rank the seventh-highest number of cases of child marriage, according to a

\footnotetext{
${ }^{5}$ Ibid paragraph (2)

${ }^{6}$ Article 7 paragraph (1) of Law No. 16 of 2019 regarding amendments to Law No. 1 of 1974 concerning Marriage.

${ }^{7}$ Ibid article 7 paragraph (2)

8 This number may not reflect the real situation because many of the marriages at this age were disguised as marriages of girls over the age of 16 or were not registered. See Mark Evenhuis, and Jennifer Burn, Just Married, Just a Child: Child Marriage in the Indo-Pacific Region (Melbourne: Plan International Australia, 2014), p. 26.
} 
UNICEF report, ${ }^{9}$ and becomes one of the countries with the highest number of early marriages in the East Asia and Pacific region. ${ }^{10}$

There are a lot of cases of early age marriage in Indonesia and it happens not only in urban areas but also in rural areas. Among the cases that have appeared in the mass media is Marriage between Sheikh Puji (43 years), and LU, a young girl aged 12 years; Marriage between AR (13 years) and AM (14 years) a junior high school student in Bantaeng, South Sulawesi; Marriage between APA (17 years) and APR (15 years), in Polewali Mandar, West Sulawesi; Marriage between ZA (13 years) and IB (15 years), in Tapin, South Kalimantan; Marriage between RSR (12 years) and E (21 years) in Taroang District, Jeneponto region; ${ }^{11}$ Marriage between grandma Rohaya (71 years) and Slamet Riyadi (16 years) in South Sumatra; and so forth. ${ }^{12}$ The conditions above are of course very worrying because many children have lost their rights that should be protected by the state.

The rise of child marriage in people's lives has a causal relationship with various factors, ranging from economic, educational, environmental, social, family, to psychological factors. ${ }^{13}$ Several other researchers have included cultural factors which include: community culture, matchmaking, parents who are not ready to guard their child's development, causing promiscuity, too close relationships in dating, and pregnancy outside of marriage. ${ }^{14}$ Apart from that, society's perspective on the institution of

9 UNICEF, "Indonesia on the Seventh Rank of Child Marriage" Running Texts on INews TV', 2017.

${ }^{10}$ Badan Pusat Statistik (BPS) dan UNICEF, p. 1.

115 Pernikahan Usia Dini yang Sempat Heboh di Indonesia Halaman All - Kompas. Com' <https://regional.kompas.com/read/2018/07/23/17281651/5-pernikahan-usia-dini-yangsempat-heboh-di-indonesia?page=all $>$.

12 'Nikah Beda Usia, Begini Kabar Pasutri Nenek Rohaya dan Slamet Riyadi Sekarang, Penampilan Berubah - Sriwijaya Post' <https://palembang.tribunnews.com/2019/06/22/nikahbeda-usia-begini-kabar-pasutri-nenek-rohaya-dan-slamet-riyadi-sekarang-penampilan-berubah> .

${ }^{13}$ Siti Munawwaroh, 'Studi Terhadap Pernikahan Usia Dini di Kecamatan Seberang Ulu I Kota Palembang Ditinjau dari Hukum Islam', Jurnal Intelektualita: Keislaman, Sosial dan Sains, 5.1 (2016), 35-44 (p. 44).

${ }^{14}$ Musyarrofa Rahmawati, Hanif Nur Widhiyanti, and Warkum Sumitro, 'Efektivitas Pembatasan Usia Perkawinan Berdasarkan Undang-Undang Nomor 1 Tahun 1974 Tentang Perkawinan', Jurnal Ilmiah Pendidikan Pancasila dan Kewarganegaraan, 3.1 (2018), 100-105 (p. 100). 
marriage also has a significant contribution, in which the phenomenon of early marriage eventually becomes a mechanism to ease the economic burden on the family. ${ }^{15}$

Regardless of the factors underlying this phenomenon, what is certain is that this situation, if left unchecked, will hinder the achievement of the goals of the state as set out in the Preamble of the 1945 Constitution of the Republic of Indonesia. ${ }^{16}$ For this reason, government policies that will regulate the issue of maturity of marriage age are necessary, not only as a means of controlling or as a means of legitimacy for the ruler over his people, but more importantly as a means to develop society and to solve the problems of people's lives which are increasingly complex. ${ }^{17}$

\section{Chronology of Issuance of Law No. 16 of 2019}

Before the issuance of Law no. 16 of 2019, the minimum age limit for marriage in Indonesia was regulated in Law Number 1 of 1974 concerning Marriage. According to the law, the minimum age for marriage for men is 19 years, and for women 16 years. ${ }^{18}$ This provision was subsequently challenged by a Judicial Review petition filed by the Legal Counsel from the 18+ Coalition acting on behalf of 3 (three) figures, namely: Endang Wasrinah, Maryanti, and Rasminah. The application was filed in April 2017 and was recorded as case number 22 / PUUXV / 2017 regarding the review of Law Number 1 of 1974 concerning Marriage. ${ }^{19}$ The Constitutional Court, through its ruling, subsequently

${ }^{15}$ Indraswari, 'Fenomena Kawin Muda dan Aborsi: Gambaran Kasus', in Menakar "Harga" Perempuan, cet. Ke-2 (Bandung: MIzan, 1999), pp. 131-32.

16 'Kontroversi Putusan MK Soal Batas Usia Pernikahan' <https://news.detik.com/ berita/d-4342917/kontroversi-putusan-mk-soal-batas-usia-pernikahan> [accessed 26 May 2019].

${ }^{17}$ H. Yacob Djasmani, 'Hukum Sebagai Alat Rekayasa Sosial dalam Praktek Berhukum di Indonesia' |Masalah-Masalah Hukum, p. 366 <https://ejournal.undip.ac.id/index.php/mmh/ article/view/13076> .

${ }^{18}$ Article 7 paragraph (1) of Law No. 1 of 1974 concerning Marriage.

${ }_{19}$ Previously, in 2014, the similar application for Judicial Review was submitted by some non-governmental organizations that are members of the 18+ Coalition, including End Child Prostitution, Child Pornography \& Trafficking of Children For Sexual Purposes (ECPAT Indonesia), Independent Youth Alliance (ARI) ), The Institute for Criminal Justice System (ICJR), the Indonesian Women's Coalition for Justice and Democracy (KPI), the Indonesian Family Planning Association (PKBI), and Online Law; Unfortunately, however, their application was rejected. 
granted some of the petitioner's petition and stated that as long as the phrase "16 (sixteen) years of age" in Article 7 paragraph (1) of Law no. $1 / 1974$ is against the Constitution and has no binding legal force.

As a follow-up to the Constitutional Court's decision, the Legislation Body (BALEG) submitted a proposal for amendments to Law no. 1 of 1974 concerning Marriage into the Open Cumulative Bill List. With the support of 24 members, the bill was then discussed at the Legislation Body (BALEG), which then formed a Working Committee (PANJA) which was tasked with conducting further discussions. In PANJA meetings, there was a debate over the minimum age of marriage for women. Various proposals were made, starting from 17 (seventeen), 18 (eighteen), and 19 (nineteen) with their respective arguments. However, at the Working Meeting with the Government on September 12, 2019, it was decided to equalize the minimum age of marriage for women and men to 19 (nineteen) years. ${ }^{20}$ Apart from that, PANJA was also of the opinion that the Bill on Amendments to Law Number 1 of 1974 concerning Marriage can be continued in the discussion at Level II, namely decisions making session so that the Bill on Amendments to Law Number 1 of 1974 concerning Marriage can be stipulated as Law. ${ }^{21}$

In parliamentary sessions, of the 10 (ten) factions in the DPR, 8 (eight) factions approved the change, while 2 (two) factions, namely F-PKS and F-PPP, remained at the age of 18. After going through tough and long debates, finally at the Plenary Session on Monday, September 16, 2019, the DPR approved the Limited Amendment to Law No. 1 of 1974 concerning Marriage by increasing the minimum age of marriage for women and men to be 19 years old. Apart from that, the Law also tightens the provision of dispensation; which, according to the previous regulation, if the prospective bride is not yet old enough, the parents can choose to apply for a dispensation to the court or other officials. In the new regulation, however, the dispensation can only be given through

${ }^{20}$ Apart from Article 7 paragraph (1), it was also agreed that amendments to paragraphs 2,3 , and 4 of the same article and the addition of new articles were inserted between articles 65 and 66.

${ }^{21}$ Ibid 
a court process and should be accompanied by very urgent reasons and supported by sufficient evidence as well.

\section{The Importance of Increasing the Minimum Age for Marriage}

\section{a. Eliminate Discrimination and Legal Conflicts}

One of the considerations of the Constitutional Court in determining the decision on the case number 22 / PUU-XV / 2017 concerning the application for Judicial Review against article 7 of Law No. 1/1974 concerning marriage is because the difference in the minimum age limit for marriage between men and women is seen as a form of discrimination. This discrimination is not only in the context of exercising the right to form a family but also discrimination against the protection and fulfillment of children's rights as guaranteed in Article 288 of the 1945 Constitution. It is further stated that the differentiation of treatment/discrimination between men and women has an impact on or hinders the fulfillment of basic rights or constitutional rights of citizens, including civil, political, economic, educational, social, and cultural rights.

\section{b. Preventing Child Marriage}

Child marriage is a complete form of violence, whether physically, mentally, sexually, or socially. Defenders of child rights even refer to child marriage as a form of legalizing rape of children in the name of marriage because, according to them, all forms of sexual relations with children are rape. Indonesia is one of the 116 member states of the United Nations (UN) that approved the results of the UN agreement on specific targets in the Post-2015 Sustainable Development Goals, one of which is to eliminate child marriage.

According to Article 1 number 1 of Law No. 35 of 2014 concerning Amendments to Law Number 23 of 2002 concerning Child Protection, a person is categorized as a child when he/she is not yet 18 (eighteen) years old and is included in this case is a child who is still in the womb. Using this provision perspective, the minimum age limit for marriage as regulated in Article 7 paragraph (1) of Law No. 1/1974 concerning 
marriage is, therefore, a form of legalization against the occurrence of child marriage, especially for girls. Thus there has been a contradiction between legal norms which will have implications for irregularities in the application of the law, especially to protect children in Indonesia. With the increase in the minimum age limit for marriage, from 16 to 19, it will automatically exclude Indonesian law from the legalization of child marriage, also, at the same time, it shows evidence of the state's commitment to the implementation of the UN agreement.

\section{c. Preventing Human Rights Violations}

Early marriage violates at once three conventions namely: the Convention on the Rights of the Child (KHA), the Convention on the Elimination of All Forms of Discrimination against Women (CEDAW), and the Universal Declaration of Human Rights (UDHR). Among the rights that are violated in early marriage are:

1) The right to education; with early age marriage, certain children's rights are denied, such as to get an education, play, and fulfill the child's potential;

2) The right to live free from violence and harassment including sexual violence; Early marriage increases the vulnerability of girls to physical, sexual, and mental violence;

3) The right to health. Early marriage can increase a girl's risk of illness and death related to pregnancy and early delivery. Besides that, it also implies the lack of control of girls over their bodies, including the sexual and reproductive abilities of the children themselves;

4) The right to be protected from exploitation; the occurrence of early childhood marriage occurs without the consent of the child or involves coercion which results in decisions aimed at taking advantage or harming the child rather than ensuring that the child's best interests are met;

5) The right not to be separated from parents; Early marriage causes girls to be separated from the family and places children in foreign 
relationships and environments that are very vulnerable to children not being cared for or protected because children do not have the power to make decisions in determining their own life. ${ }^{22}$

In this regard, two policy concepts can be developed by the government as a form of taking sides with the interests of children. First, development policies that give important attention to the welfare and protection of children or are called the "Child Mainstreaming Policy". Second, the child-friendly development policy or the so-called "ChildFriendly Policy", for the sake of the integrity of children's growth and development in facing the future of the nation and state. ${ }^{23}$

\section{d. Preparing the physical and mental abilities of the bride and groom}

Even though in Muslim countries there is no uniformity regarding the ideal limit for a person to get married, ${ }^{24}$ there is still a common view that to achieve a harmonious, happy, and prosperous household life it requires maturity and physical and mental readiness both on the part of the husband and from the side of the wife. ${ }^{25}$ Marriage at an early age, as it is often the case in rural areas, will result in a wife, who is still classified as a child, unfit to act as a wife as well as the mother of her children. This unpreparedness has the potential to cause many problems, both for the mother herself and for the development of her children. With the maturity of the bride and groom, especially for women, healthy and quality offspring can be obtained, thus, reducing the risk of maternal and child mortality. In addition, the physical and mental growth of children can be more optimal because they receive assistance from their parents who have adequate levels of maturity both psychologically and socially.

${ }^{22}$ Badan Pusat Statistik (BPS) dan UNICEF, pp. 9-10.

${ }^{23}$ Sugianto, 'Menghindari Kekerasan Terhadap Anak Menurut Perspektif Undang-Undang Perlindungan Anak' De Jure: Jurnal Hukum dan Syar'iah, pp. 67-68<http://ejournal.uin-malang. ac.id/index.php/syariah/article/view/2159>.

${ }^{24}$ Abdul Qodir Zaelani, 'Konsep Ta’aqquli dan Ta’abbudi dalam Konteks Hukum Keluarga Islam', $A S A S, 6.1$ (2014), p. 4 <https://doi.org/10.24042/asas.v6i1.1708>.

${ }^{25}$ Muhammad Jazil Rifqi, 'Analisis Utilitarianisme Terhadap Dispensasi Nikah Pada UndangUndang Perkawinan Nomor 1 Tahun 1974', Al-Ahwal: Jurnal Hukum Keluarga Islam, 10.2 (2018), 156-64 (p. 163) <https://doi.org/10.14421/ahwal.2017.10204>. 


\section{e. Protection of children/women}

To ensure the future of the next generation, children must receive protection from all forms of harassment, threats, violence, and exploitation by adults. This protection is not only borne by the parents, but also the responsibility of the community, nation, and state. ${ }^{26}$ Legal protection is needed to safeguard the rights of every citizen, both women, and men. The Quran has discussed a lot and hinted at humans that the protection of children is a duty and obligation of parents that must be carried out since childhood. ${ }^{27}$ Therefore, for every child to be able to assume responsibility as a successor to the ideals of the nation's struggle, they need to get the widest possible opportunity to live and develop optimally, both physically, mentally, socially, and with noble character. ${ }^{28}$

Emphasizing on protection for women does not necessarily mean that men do not need protection in a marriage bond. However, the tendency of women, who are not yet ready to marry, will be vulnerable to causing certain negative effects and risks that will arise as a result of the husband's and wife's unpreparedness to navigate marriage. If these negative conditions arise, then the most vulnerable parties to become victims are women.

\section{f. Prevent marriage crime}

Marriage crimes can occur both before and after marriage. Crimes that occurred before marriage were generally in the form of age manipulation. Meanwhile, crimes that occur after marriage include crimes in the household (KDRT) and some other violations related to fulfilling the rights and obligations of one of the two spouses.

For crimes in the form of age manipulation and forced marriage, this has been mitigated by the increasingly tightening of provisions on

${ }^{26}$ Siti Nurjanah, 'Keberpihakan Hukum Islam Terhadap Perlindungan Anak', AL-'ADALAH, 14.2 (2017), 391-432 (p. 391) <https://doi.org/10.24042/adalah.v14i2.2905>.

${ }^{27}$ Abdul Mustaqim, 'Kedudukan dan Hak-Hak Anak dalam Perspektif Al-Qur'an (Sebuah Kajian dengan Metode Tafsir Tematik)', Musäwa Jurnal Studi Gender dan Islam, 4.2 (2006), 145-69 (pp. 149-50) <https://doi.org/10.14421/musawa.2006.42.145-169>.

${ }^{28}$ Muhammad Zaki, 'Perlindungan Anak dalam Perspektif Islam', ASAS, 6.2 (2014), p. $3<$ https://doi.org/10.24042/asas.v6i2.1715>. 
marriage dispensation, which originally under Article 7 paragraph (2) of Law no. 1 of 1974 can be obtained from 2 channels, namely through courts or other officials requested by the parents of the male or female parties. $^{29}$ This provision, by Law no. 16 of 2019, was changed by providing only one channel, namely the court and that too must be supported by concrete evidence and very urgent reasons. As for crimes that occur after marriage, this has been regulated in detail in Law Number 23 of 2004 concerning the Elimination of Domestic Violence in which all forms of violence against women physically, emotionally, socially, sexually, and economically are punishable by criminal penalties.

\section{g. Reducing the divorce rate}

Undeniably, physical and mental maturity for someone intending to carry out marriage is an important aspect that must receive attention because it has a significant influence in determining success in building a harmonious household life. ${ }^{30}$ Personal maturity and integrity in realizing the goal of marriage are indispensable in solving problems in the household. Many divorce cases occur due to the unpreparedness of husbands and wives in overcoming household problems as they marry at an early age. ${ }^{31}$ Someone who gets married early in life can only interpret love in the household as mere beauty and romance. At this time there is only love that is not yet bound by a perfect sense of responsibility. ${ }^{32}$ Meanwhile, all actions that are carried out in marriage are actions that require great responsibility and deep understanding from the husband and wife. By maturing the age of marriage, it is hoped that the association between husband and wife can run respectably in a calm, peaceful, and affectionate atmosphere. ${ }^{33}$

${ }^{29}$ Ibid article 7 paragraph (2)

${ }^{30}$ Suhadi, 'Pernikahan Dini, Perceraian, dan Pernikahan Ulang: Sebuah Telaah dalam Perspektif Sosiologi', Komunitas: International Journal of Indonesian Society and Culture, 4.2 (2012), p. 168 <https://doi.org/10.15294/komunitas.v4i2.2412>.

${ }^{31}$ Ahmad Ropik, Hukum Islam di Indonesia, Cet. ke-6 (Jakarta: PT. Raja Grafindo Persada), pp. 77-78.

${ }^{32}$ Sarwito Wirawan Sarwono, Memilih Pasangan dan Merencanakan Perkawinan (Jakarta: Bina Keluarga, BKKBN, 1981), p. 12.

${ }^{33}$ Iswantoro Iswantoro, 'Penyelesaian Sengketa Harta Perkawinan Pasca Putusan Mahkamah 


\section{h. Expanding opportunities for education}

Among the main functions of education are as an enforcer of values, a means of community development, and a means to develop human potential. Unfortunately, these functions have not yet been fully implemented optimally. According to a survey by the Central Statistics Agency (BPS), in 2015 there were $91.12 \%$ of girls who were married before 18 years of age who failed to complete high school education. ${ }^{34}$ This condition is opposed to the wishes of Article 31 of the 1945 NKRI Constitution which states that "every citizen has the right to 12 years of basic education".

Government policy in regulating the problem of maturity of the marital age is necessary to adopt the development of society and to solve the problems of community life in the future which are increasingly complex. ${ }^{35}$ Setting the minimum age limit for marriage too low may cause girls to lose their right to basic education for 12 years, because, although the law does not prohibit, many schools in Indonesia refuse married girls to attend school. ${ }^{36}$ This situation will practically eliminate the child's right to obtain basic education; whereas basic education has become the main priority for developing human resources from an early age, although in the short term the benefits obtained from higher education are still unpredictable. ${ }^{37}$

\section{i. Increasing family welfare and economy}

The level of a person's welfare is closely related to the level of satisfaction (utility) and pleasure that can be achieved in life to achieve the desired level of welfare. For that, we need behavior that can maximize

Konstitusi Nomor 69/PUU-XIII/2015', Al-Ahwal: Jurnal Hukum Keluarga Islam, 11.1 (2018), 43-58 (p. 43) <https://doi.org/10.14421/ahwal.2018.11104>.

${ }^{34}$ Mark Evenhuis, and Jennifer Burn, p. 25.

${ }^{35}$ H. Yacob Djasmani, p. 336.

${ }^{36}$ The Jakarta Post, 'Aceh Student Expelled from School over Marriage', The Jakarta Post $<$ https://www.thejakartapost.com/news/2015/01/23/aceh-student-expelled-school-over-marriage. htmls.

${ }^{37}$ Michael P Todaro, Pembangunan Ekonomi di Dunia Ketiga (Jakarta: Erlangga, 2003), p. 404 . 
the level of satisfaction following the available resources. ${ }^{38}$ The concept of welfare cannot be separated from the quality of life of the community, meanwhile, the quality of life of the community is also influenced by the socio-political and economic conditions of the community. ${ }^{39}$

Educational background, either directly or indirectly, will affect human capacity as the main capital in achieving family welfare. The low level of education is a problem that is vulnerable and has a lasting impact on families, and can even be a cause of recurring poverty. According to Kuncoro, this is because access to high-paying jobs in both the government and private sectors depends on high levels of education. ${ }^{40}$

As confirmed by Rozana Himaz, higher education allows for higher benefits, because the education variable is positively correlated with the income variable through the quality of workers. ${ }^{41}$ The higher a person's education level, the greater the opportunity for him to get reciprocity in the form of a stable job and an adequate income. This indicator of the effect of education can be seen by comparing the number of elementary, junior, and senior high school graduates among workers with the level of their economic ability which is used in calculating the Gross Domestic Product (GDP). ${ }^{42}$ Increasing the minimum age limit for marriage, especially for women, opportunities for them to continue their education to a higher level as well as to get more decent work is more achievable. Children who drop out of school due to early marriage will have minimal job opportunities, which in turn will greatly affect the economic welfare of the family.

${ }^{38}$ Amir Mu'allim, 'Ijtihad Ekonomi dalam Pengelolaan Aset Wakaf', $A L$-'ADALAH, 14.2 (2017), 291-310 (p. 299) <https://doi.org/10.24042/adalah.v14i2.2212>.

39 Astriana Widyastuti, 'Analisis Hubungan Antara Produktivitas Pekerja dan Tingkat Pendidikan Pekerja Terhadap Kesejahteraan Keluarga di Jawa Tengah Tahun 2009 | Economics Development Analysis Journal', p. 3 <https://journal.unnes.ac.id/sju/index.php/edaj/article/ view/472>.

${ }^{40}$ Mudrajat Kuncoro, Ekonomi Pembangunan Teori, Masalah dan Kebijakan (Yogyakarta: UPP AMP YKPN, 1997), p. 124.

${ }^{41}$ Rozana Himaz, Education and Household Welfare in Sri Lanka from 1985 to 2006 (DC. U.S.A: University of Oxford, Washington, 1985), p. 2.

${ }^{42}$ B. Murti, 'Hubungan Antara Tingkat Pendidikan dan Hipertensi Pada Wanita di Kabupaten Sukoharjo - PDF Free Download', Adoc.Pub, pp. 1-2 <https://adoc.pub/hubunganantara-tingkat-pendidikan-dan-hipertensi-pada-wanit.html> . 


\section{j. Improving the quality of human resources}

Development is influenced by various factors; not only by high economic growth, but also by the condition of the country's human resources. ${ }^{43}$ In countries where humans are the main foundation for the welfare of the country, the quality of human resources is positioned as the ultimate goal of development, not just an object or tool. For this reason, development programs need to be directed at human-centered development concepts and strategies with the ultimate goal of enabling them to compete in all aspects of life both nationally and globally. ${ }^{44}$

\section{k. Reformulation of Islamic Family Law in Indonesia.}

Islamic Family Law in Indonesia can be found in the Compilation of Islamic Law (KHI) which is one of the sources of law for the Muslim community in the country. The historical facts show that the aims and objectives of the formation of the Marriage Law and KHI itself are inseparable from the background of the existence of Muslims in Indonesia which occupies the majority position among the people ${ }^{45}$

This position, in many respects, also relates to the provisions contained in the Marriage Law, one of which is the minimum age for marriage. Historical facts show that the emergence of the minimum age limit for marriage in the Marriage Law began with a discussion held by the government and representatives of ulama, in which one of the points of debate that emerged and heated was about the minimum age limit for marriage. In the Draft Law on Marriage, the government offers the minimum age for marriage 18 years for women and 21 years for men. This provision was rejected by Muslim scholars. After a long discussion, however, they reached an agreement to set the age limit

${ }^{43}$ Ely Kusuma Retno, Pengaruh Pendidikan dan Kemiskinan Terhadap Pertumbuhan Ekonomi di Indonesia (Surabaya: FE. UNESA), p. 2.

${ }^{44}$ Durrotul Mahsunah, 'Analisis Pengaruh Jumlah Penduduk, Pendidikan dan Pengangguran Terhadap Kemiskinan di Jawa Timur' (Surabaya: Fakultas Ekonomi Universitas Negeri Surabaya), p. 14.

${ }^{45}$ Nur Faizah, 'Konsep Qiwāmah dalam Yurisprudensi Islam Perspektif Keadilan Gender', Al-Ahwal: Jurnal Hukum Keluarga Islam, 11.1 (2018), 13-22 (p. 17) <https://doi.org/10.14421/ ahwal.2018.11102>. 
to be 16 years for women and 19 years for men. The result of this agreement was then stated in Article 7 paragraph (1) of Law No. 1 of 1974 concerning Marriage. These provisions are subsequently adopted by the Compilation of Islamic Law (KHI) as contained in Article 15 paragraph (1) of the KHI which reads, "For the benefit of the family and household, marriage may only be performed by the prospective bride who has reached the age stipulated in Article 7. Law No. 1 of 1974, namely the future husband is at least 19 years old and the future wife is at least 16 years old".

Furthermore, to adopt emergency and urgent possibilities, the Law, through Article 7 paragraph (2), provides space for dispensation for couples who have not reached the age of marriage, using both the male and female parents requesting dispensation to the Court or other appointed officials. The provisions regarding this dispensation were followed up by the issuance of Regulation of the Minister of Religion Number 3 of 1975 concerning the Obligations of Marriage Officers and the Work Procedure of the Religious Courts in Implementing Marriage Legislation for Muslims. In Article 8 letter (e), the Ministerial Regulation stipulates that prospective husbands who have not reached the age of 19 and/or prospective wives who are not yet 16 years old to be able to enter into marriage must submit a dispensation permit for marriage issued by the Religious Court.

In Islamic law itself, there is no minimum age limit for marriage. This limitation is only based on a biological condition, namely what is known as aqil baligh, ${ }^{46}$ or mukallaf, namely a person who is worthy enough to be given a burden on him to carry out actions ordered by religion. ${ }^{47}$ With this condition, it is hoped that the couple who wants to get married will have mental maturity. ${ }^{48}$ The standard status of baligh (mukallaf) itself only provides legitimacy to perform syar'iy deeds, including in this area of marriage; while the order to marry

\footnotetext{
${ }^{46}$ Rahmawati, Widhiyanti, and Sumitro, p. 101.

${ }^{47}$ Ali Hasballah, Usul Al-Tasyri al Islami, (Kairo: Dar ar-Ma’arif, tt), p. 392.

${ }^{48}$ Rifqi, p. 163.
} 
someone who can do so is known as al-ba'ah. ${ }^{49}$ In short, according to Islamic law, marriages that occur in people's lives must be carried out by people who are aqil (perfect intellect) and baligh (mature), in the sense that they have physical readiness, mental, emotional, and mental maturity, to maintain the continuity of the marriage. ${ }^{50}$

Classical fiqh does not provide specific discussion regarding the minimum age for marriage, other than about aqil-balig. ${ }^{51} \mathrm{Al}-\mathrm{Quran}$ itself has given the flexibility to Muslims to regulate legal and statutory affairs related to the benefit of their life in this world. This shows evidence of the dynamic space and breadth of Islamic law which is an objective implementation of Islamic doctrine, which, although it stands on absolute and solid truth, also has dynamic space for development and renewal following the flexibility of time and space. ${ }^{52}$

Meanwhile, the struggle of Islamic law with the realities of the times demands a positive response and the role of Islamic law amid community life both as a controller, empowerment, and as a supporter of social welfare. This response and role are needed so that Islamic law does not experience a crisis and is ineffective amid the increasingly complex developments of society. ${ }^{53}$ Stagnation in thinking will give birth to weak legal products. For this reason, seriousness in reformulating fiqh thinking about Islamic family law in Indonesia is a necessity that must be followed up. A review of the products of previous scholars'

49 The meaning of $a l-b a$ a'ah refers to one of the abilities and feasibility of carrying out a marriage according to Islamic teachings. See Riyanto, 'Batas Minimal Usia Menikah (Studi Komparatif Antara INPRES NO. 1 Tahun 1991 Tentang Kompilasi Hukum Islam Dan Counter Legal Draft (CLD’ (Fakultas Syariah UIN SUKA, 2009), p. 53.

${ }^{50}$ Ropida, Ni Luh Nyoman Kebayanti, dan Ikma Citra Ranteallo,'Pilihan Rasional Perempuan Menikah di Usia Dini (Studi Kasus di Desa Mamben Daya, Kecamatan Wanasaba, Kabupaten Lombok Timur) | JURNAL ILMIAH SOSIOLOGI (SOROT)', p. 93 <https://ojs. unud.ac.id/index.php/sorot/article/view/23778>.

${ }^{51}$ Winengan Winengan, 'Politik Hukum Keluarga Islam di Aras Lokal: Analisis Terhadap Kebijakan Pendewasaan Usia Pernikahan di Nusa Tenggara Barat', Al-Ahwal: Jurnal Hukum Keluarga Islam, 11.1 (2018), 1-12 (p. 1) <https://doi.org/10.14421/ahwal.2018.11101>.

${ }_{52}$ Masnun Tahir, 'Menjadi Muslim di Negara Multikultural: Dinamika, Tantangan dan Strategi dalam Perspektif Fikih Multikultural', $A L-' A D A L A H, 14.2$ (2017), 263-90 (p. 284) <https://doi.org/10.24042/adalah.v14i2.2138>.

${ }^{53}$ Maulidi Maulidi, 'Menggagas Fikih Responsif: Upaya Progresif Modernisasi Fikih', $A L-' A D A L A H, 14.2$ (2017), 507-28 (p. 517) <https://doi.org/10.24042/adalah.v14i2.2677>. 
thoughts should often be done to harmonize fiqh with the development and change of society both for the present and the future. ${ }^{54}$ This means that the possibility of revising legal products will always exist along with changes in time, place, and circumstances. ${ }^{55}$ The revisions can be done in various ways which includes choosing various legal systems (the eclectic expedient), making reforms in the procedural law or the field of administration (the executive of administrative orders); or against decisions that have legal force (the expedient of reform by judicial decision)..$^{56}$

Truly, the law must always move dynamically in bringing benefit to mankind; Therefore, it is ideal, or maybe it can be considered as mandatory for every Muslim to have the ability to understand, and at the same time, to apply the principles that exist in Islamic law for the benefit of humankind. ${ }^{57}$

\section{Conclusion}

Government policy regulating the issue of maturity of marriage through the issuance of Law Number 16 of 2019 concerning Amendments to Law Number 1 of 1974 concerning Marriage is necessary. This is to adopt the development of society and to solve the recent and future problems of people's life which are increasingly complex. The determination of the minimum age limit for marriage in the rules of the Marriage Law aims to prepare couples who are going to marry to be physically and mentally prepared, as well as provide wider opportunities for each party to get a proper education so that they can play an active

${ }^{54}$ Ilyasin, 'Filsafat Hukum Islam: Implikasi Logis Terhadap Konstruksi Pendidikan Islam, Asy-Syir'ah: Jurnal Ilmu Syariah dan Hukum', p. 552 <http://asy-syirah.uin-suka.com/index.php/ AS/article/view/50>.

${ }^{55}$ Ahmad Rajafi, 'Hukum Keluarga Islam di Indonesia: dari Orde Lama hingga Orde Reformasi', AL-'ADALAH, 14.2 (2017), 311-32 (p. 313) <https://doi.org/10.24042/adalah. v14i2.2059>. $13-14)$.

${ }^{56}$ Fathurrahman Djamil, 'Reaktualisasi dan Legislasi Hukum Islam', 1, 1996, 13-14 (pp.

${ }^{57}$ A. Fanani, 'Usul Al-Fiqh versus Hermeneutika Tentang Pengembangan Pemikiran Hukum Islam Kontemporer | ISLAMICA: Jurnal Studi Keislaman', pp. 194-209 <http://islamica.uinsby. ac.id/index.php/islamica/article/view/68> 
role in supporting the economic productivity of the family, as well as to be a quality human being in the future.

On the other hand, efforts to reform the classical figh thought on Islamic family law in Indonesia, especially KHI, has also become an urgent need, considering that the struggle of Islamic law with the realities of the times demands a positive response and the role of Islamic law in people's lives. A review of the products of previous ulama thoughts should often be done to harmonize figh with the development and changes of society. Only in this way does Islamic Law not experience a crisis and ineffectiveness amid the development of community life, and can continue to appear as a controller, empowerment, and support for social welfare.

\section{Bibliography}

Assegaf, Abd. Rachman, Studi Islam Kontekstual Elaborasi Paradigma Baru Muslim Kaffah, Yogyakarta: Gema Media, 2005.

Badan Pusat Statistik (BPS) dan UNICEF, Kemajuan Tertunda: Analisis Data Perkawinan Usia Anak di Indonesia, Jakarta: Badan Pusat Statistik, 2015.

Djasmani, H. Yacob, Hukum Sebagai Alat Rekayasa Sosial dalam Praktek Berhukum di Indonesia' | Masalah-Masalah Hukum'<https://ejournal. undip.ac.id/index.php/mmh/article/view/13076>

Djamil, Fathurrahman, 'Reaktualisasi Dan Legislasi Hukum Islam', 1, 1996, 13-14

Durrotul Mahsunah, Analisis Pengaruh Jumlah Penduduk, Pendidikan Dan Pengangguran Terhadap Kemiskinan di Jawa Timur, Surabaya: Fakultas Ekonomi Universitas Negeri Surabaya,tt.

Faizah, Nur, 'Konsep Qiwāmah dalam Yurisprudensi Islam Perspektif Keadilan Gender', Al-Ahwal: Jurnal Hukum Keluarga Islam, 11.1 (2018), 13-22 <https://doi.org/10.14421/ahwal.2018.11102>

Fanan, A. 'Usul Al-Fiqh versus Hermeneutika Tentang Pengembangan Pemikiran Hukum Islam Kontemporer' | ISLAMICA: Jurnal Studi Keislaman, <http://islamica.uinsby.ac.id/index.php/islamica/article/ view/68>. 
Hasballah, Ali. Usul Al-Tasyri al Islami, Kairo: Dar ar-Ma'arif, tt.

H. M. A Tihami and Sohari Sahrani, Fikih Munakahat: Complete Marriage Figh Study, Jakarta: Raja Grafindo Persada, 2014.

Ilyasin, 'Filsafat Hukum Islam: Implikasi Logis Terhadap Konstruksi Pendidikan Islam' | Asy-Syir'ah: Jurnal Ilmu Syariah dan Hukum <http://asy-syirah.uin-suka.com/index.php/AS/article/view/50>

Indraswari, 'Fenomena Kawin Muda dan Aborsi: Gambaran Kasus', in Menakar "Harga" Perempuan, cet. Ke-2, Bandung: Mizan, 1999.

Iswantoro, Iswantoro, 'Penyelesaian Sengketa Harta Perkawinan Pasca Putusan Mahkamah Konstitusi Nomor 69/PUU-XIII/2015', AlAhwal: Jurnal Hukum Keluarga Islam, 11.1 (2018), 43-58 <https:// doi.org/10.14421/ahwal.2018.11104>

'Kontroversi Putusan MK Soal Batas Usia Pernikahan' <https://news. detik.com/berita/d-4342917/kontroversi-putusan-mk-soal-batas-usiapernikahan>

Kuncoro, Mudrajat, Ekonomi Pembangunan Teori, Masalah dan Kebijakan, Yogyakarta: UPP AMP YKPN, 1997.

Mark Evenhuis, and Jennifer Burn, Just Married, Just a Child: Child Marriage in the Indo-Pacific Region (Melbourne: Plan International Australia, 2014)

Maulidi, 'Menggagas Fikih Responsif: Upaya Progresif Modernisasi Fikih', AL-'ADALAH, 14.2 (2017), 507-28 <https://doi.org/10.24042/ adalah.v14i2.2677>

Murti, B. 'Hubungan Antara Tingkat Pendidikan dan Hipertensi Pada Wanita di Kabupaten Sukoharjo - PDF Free Download', Adoc. Pub <https://adoc.pub/hubungan-antara-tingkat-pendidikan-danhipertensi-pada-wanit.html>.

Mu'allim, Amir, 'Ijtihad Ekonomi dalam Pengelolaan Aset Wakaf', $A L$ 'ADALAH, 14.2 (2017), 291-310 <https://doi.org/10.24042/adalah. v14i2.2212>

Munawwaroh, Siti, 'Studi Terhadap Pernikahan Usia Dini di Kecamatan Seberang Ulu I Kota Palembang Ditinjau dari Hukum Islam', Jurnal Intelektualita: Keislaman, Sosial dan Sains, 5.1 (2016), 35-44. 
Mustaqim, Abdul, 'Kedudukan dan Hak-Hak Anak Dalam Perspektif Al-Qur'an (Sebuah Kajian Dengan Metode Tafsir Tematik)', Musãwa Jurnal Studi Gender Dan Islam, 4.2 (2006), 145-69 <https://doi. org/10.14421/musawa.2006.42.145-169>

'Nikah Beda Usia, Begini Kabar Pasutri Nenek Rohaya Dan Slamet Riyadi Sekarang, Penampilan Berubah - Sriwijaya Post' < https://palembang. tribunnews.com/2019/06/22/nikah-beda-usia-begini-kabar-pasutrinenek-rohaya-dan-slamet-riyadi-sekarang-penampilan-berubah>.

Nurjanah, Siti, 'Keberpihakan Hukum Islam Terhadap Perlindungan Anak', AL-'ADALAH, 14.2 (2017), 391-432 <https://doi.org/10.24042/ adalah.v14i2.2905>

Post, The Jakarta, 'Aceh Student Expelled from School over Marriage', The Jakarta Post <https://www.thejakartapost.com/news/2015/01/23/ aceh-student-expelled-school-over-marriage.html>.

Rahmawati, Musyarrofa, Hanif Nur Widhiyanti, and Warkum Sumitro, 'Efektivitas Pembatasan Usia Perkawinan Berdasarkan UndangUndang Nomor 1 Tahun 1974 Tentang Perkawinan', Jurnal Ilmiah Pendidikan Pancasila dan Kewarganegaraan, 3.1 (2018), 100-105

Rajafi, Ahmad, 'Hukum Keluarga Islam di Indonesia: dari Orde Lama hingga Orde Reformasi', AL-'ADALAH, 14.2 (2017), 311-32 $<$ https://doi.org/10.24042/adalah.v14i2.2059>

Rifqi, Muhammad Jazil, 'Analisis Utilitarianisme Terhadap Dispensasi Nikah Pada Undang-Undang Perkawinan Nomor 1 Tahun 1974', AlAhwal: Jurnal Hukum Keluarga Islam, 10.2 (2018), 156-64 <https:// doi.org/10.14421/ahwal.2017.10204>

Riyanto, 'Batas Minimal Usia Menikah (Studi Komparatif Antara INPRES NO. 1 Tahun 1991 Tentang Kompilasi Hukum Islam Dan Counter Legal Draft (CLD’ (Fakultas Syariah UIN SUKA, 2009)

Rozana Himaz, Education and Household Welfare in Sri Lanka from 1985 to 2006 (DC. U.S.A: University of Oxford, Washington, 1985)

Ropida, Ni Luh Nyoman Kebayanti, dan Ikma Citra Ranteallo, 'Pilihan Rasional Perempuan Menikah di Usia Dini (Studi Kasus di Desa Mamben Daya, Kecamatan Wanasaba, Kabupaten Lombok Timur)' 
| JURNAL ILMIAH SOSIOLOGI (SOROT), <https://ojs.unud.ac.id/ index.php/sorot/article/view/23778>.

Retno, Ely Kusuma, Pengaruh Pendidikan dan Kemiskinan Terhadap Pertumbuhan Ekonomi di Indonesia Surabaya: FE. UNESA, tt.

Ropik, Ahmad, Hukum Islam di Indonesia, Cet. ke-6, Jakarta: PT. Raja Grafindo Persada,tt.

Sarwito Wirawan Sarwono, Memilih Pasangan Dan Merencanakan Perkawinan, Jakarta: Bina Keluarga, BKKBN, 1981.

Suhadi, 'Pernikahan Dini, Perceraian, dan Pernikahan Ulang: Sebuah Telaah dalam Perspektif Sosiologi', Komunitas: International Journal of Indonesian Society and Culture, 4.2 (2012) <https://doi.org/10.15294/ komunitas.v4i2.2412>

Sugianto, 'Menghindari Kekerasan Terhadap Anak Menurut Perspektif Undang-Undang Perlindungan Anak' |De Jure: Jurnal Hukum dan Syar'iah' <http://ejournal.uin-malang.ac.id/index.php/syariah/article/ view/2159>.

Tahir, Masnun, 'Menjadi Muslim di Negara Multikultural: Dinamika, Tantangan dan Strategi dalam Perspektif Fikih Multikultural', $A L$ 'ADALAH, 14.2 (2017), 263-90 <https://doi.org/10.24042/adalah. v14i2.2138>

Todaro, Michael P, Pembangunan Ekonomi di Dunia Ketiga, Jakarta: Erlangga, 2003.

UNICEF, "Indonesia on the Seventh Rank of Child Marriage" Running Texts on INews TV', 2017

Widyastuti, Astriana, 'Analisis Hubungan Antara Produktivitas Pekerja dan Tingkat Pendidikan Pekerja Terhadap Kesejahteraan Keluarga di Jawa Tengah Tahun 2009' | Economics Development Analysis Journal, <https://journal.unnes.ac.id/sju/index.php/edaj/article/ view/472>

Winengan, Winengan, 'Politik Hukum Keluarga Islam di Aras Lokal: Analisis Terhadap Kebijakan Pendewasaan Usia Pernikahan di Nusa Tenggara Barat', Al-Ahwal: Jurnal Hukum Keluarga Islam, 11.1 (2018), 1-12 <https://doi.org/10.14421/ahwal.2018.11101> 
Zaelani, Abdul Qodir, 'Konsep Ta'aqquli dan Ta'abbudi dalam Konteks Hukum Keluarga Islam', ASAS, 6.1 (2014) <https://doi.org/10.24042/ asas.v6i1.1708>

Zaki, Muhammad, 'Perlindungan Anak dalam Perspektif Islam', ASAS, 6.2 (2014) <https://doi.org/10.24042/asas.v6i2.1715> 